\title{
Analysis of Demand in Mount Salak Endah Tourism Object in Bogor Regency
}

\author{
By: \\ Bunari \\ Pandu Junior High School Bogor \\ Email: bunariyasmo@yahoo.co.id
}

\begin{abstract}
This research was to find out how is the demand to visit Mount Salak Endah tourism object. From the results of demand analysis of Mount Salak Endah tourism object, it was obtained that: a) length of journey had a negative effect on the number of visits to Mount Salak Endah tourism object with a coefficient value of -0.753 ; b) length of journey to other similar tourism object (Puncak) had a positive effect on the number of visits to Mount Salak Endah tourism object with a coefficient value of 0.501 ; c) perception of admission ticket price to other similar tourism object (Puncak) had a negative effect on the number of visits to Mount Salak Endah tourism object with a coefficient value of -0.310 ; d) perception of tourism facilities in Mount Salak Endah had a positive effect on the number of visits to Mount Salak Endah tourism object with a coefficient value of 0.314; and e) perception of culinary in Mount Salak Endah had a positive effect on the number of visits to Mount Salak Endah tourism object.
\end{abstract}

Keywords: Mount Salak Endah, Demand of Tourism Object, Travel Cost Method, Perception of Tourism Facilities, Perception of Culinary.

\begin{abstract}
ABSTRAK
Penelitian ini bertujuan untuk mengetahui bagaimana permintaan untuk berkunjung ke objek wisata Gunung Salak Endah. Dari hasil analisis permintaan objek wisata Gunung Salak Endah, diperoleh bahwa: a) panjang perjalanan memiliki pengaruh negatif terhadap jumlah kunjungan ke objek wisata Gunung Salak Endah dengan nilai koefisien 0,753; b) Lama perjalanan ke objek wisata serupa lainnya (Puncak) memiliki pengaruh positif terhadap jumlah kunjungan ke objek wisata Gunung Salak Endah dengan nilai koefisien 0,$501 ;$ c) Persepsi harga tiket masuk ke objek wisata lain yang serupa (Puncak) memiliki pengaruh negatif terhadap jumlah kunjungan ke objek wisata Gunung Salak Endah dengan nilai koefisien -0,310; d) persepsi fasilitas pariwisata di Gunung Salak Endah memiliki pengaruh positif terhadap jumlah kunjungan ke objek wisata Gunung Salak Endah dengan nilai koefisien 0,314; dan e) persepsi kuliner di Gunung Salak Endah memiliki efek positif pada jumlah kunjungan ke objek wisata Gunung Salak Endah.
\end{abstract}

Kata Kunci: Gunung Salak Endah, Permintaan Objek Wisata, Metode Biaya Perjalanan, Persepsi Fasilitas Wisata, Persepsi Kuliner.

\section{INTRODUCTION}

Bogor Regency is one of the areas in West Java Province that has the potential of natural tourism and is located adjacent to DKI Jakarta. This makes the Bogor Regency as a major tourist destination, especially in nature tourism. The natural beauty of the mountains along its various advantages, makes this area to be highly demanded by the public.

Tourism potentials in Bogor Regency are nature tourism, culinary, shopping, art, cultural tourism, and special interest tourism, namely educational tourism (Hermawan, 2016). Nature tourism 
is one of the major tourist attraction offered to tourists who come to Bogor Regency (Agustine et al., 2016). The following is the data of Development Performance of Public Service Aspects on Tourism Affairs in 2008-2012 in Bogor Regency.

As a mountain with fresh air and natural beauty, Mount Salak Endah area has beautiful and natural potentials such as Kawah Ratu, waterfall and natural hot water supported by a very supportive attitude of the population (Satria, 2009). The number of tourists visiting Mount Salak Endah tourism object in Bogor from 2010 to 2012 continued to increase.

Table 1. Development Performance of Public Service Aspects on Affairs Tourism in 2008-2012

\begin{tabular}{|c|c|c|c|c|c|c|}
\hline \multirow[t]{2}{*}{ No. } & \multirow[t]{2}{*}{ Indicator } & \multicolumn{5}{|c|}{ Performance Realization } \\
\hline & & 2008 & 2009 & 2010 & 2011 & 2012 \\
\hline 1 & Tourism Visits & $2,230,010$ & $2,361,155$ & $2,597,385$ & $4,230,475$ & $4,696,627$ \\
\hline 2 & $\begin{array}{l}\text { The contribution of the tourism } \\
\text { sector to the GRDP at constant } \\
\text { prices (\%) }\end{array}$ & 2.94 & 2.93 & 2.98 & 6.21 & 3.1 \\
\hline 3 & $\begin{array}{l}\text { The contribution of the tourism } \\
\text { sector to the GRDP at } \\
\text { applicable price of (\%) }\end{array}$ & 3.06 & 3.08 & 3.12 & 19.32 & 3.14 \\
\hline
\end{tabular}

Source: Regional Development Work Plan 2014, Bogor Regency

In tourism development, there are three aspects to be considered, namely: Attractions, Amenity, and Accessibility. Seeing from the number of visits to Mount Salak Endah tourism object, it shows an increasing trend, but the visitation growth decreases. In general, the demand function of the tourism object is affected by several factors, such as the travel cost to the tourist destination and other similar tourism object, individual/community income, the length of the journey to the tourist destination and other similar tourism object, the admission price of tourism object, infrastructure, art attraction, environmental condition and culinary in the tourist destination. Thus, the purpose of the research is to analyze the effect of travel cost to Mount Salak Endah tourism object, travel cost to the other tourism object, individual income, length of journey, the perception of the admission price, perception of tourism facilities, perception of environmental condition and perception of culinary on the number of visits to Mount Salak Endah tourism object.

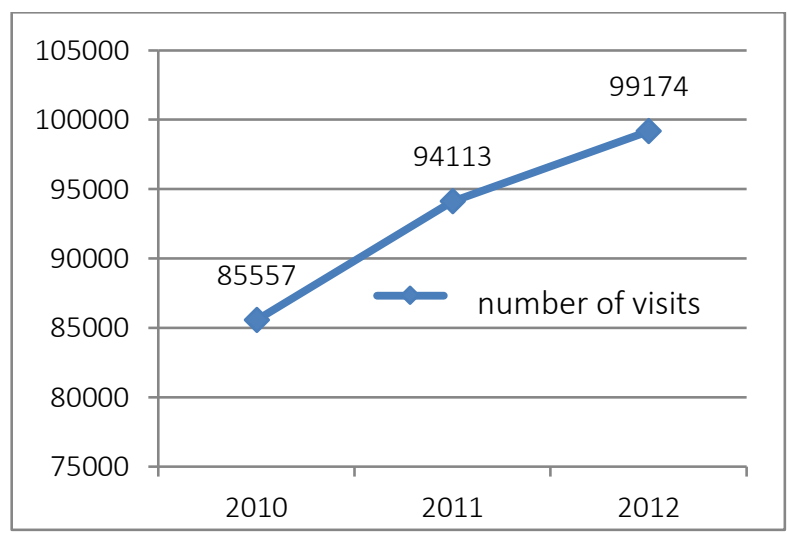

Figure 1. Number of Visits at Mount Salak Endah Nature Tourism in 2010-2012 Source: Department of Culture and Tourism Bogor Regency, 2014

\section{ANALYTICAL METHOD}

This research was conducted at Mount Salak Endah tourism object located in Pamijahan Sub-district, Bogor Regency. This location was selected because Mount Salak Endah tourism object is one of the potential tourism objects, but the management has not managed its potentials optimally. This research was conducted in December 2015 - February 2016. 
The object of this research was Mount Salak Endah tourism object located in Pamijahan Subdistrict, Bogor Regency. This research used qualitative data, data were in the form of words, not numbers. However, in the process of data analysis, the research data was transformed from qualitative data into quantitative data. This was performed through encoding the respondents' answers. According to the data source, the types of data of this research were as follows:

The research data was collected directly at the research location. The party who became the source of research data was the visitors visiting Mount Salak Endah tourism object. The data collection in this research was performed by the following methods:

(1) Questionnaire; Data collection through questionnaires was conducted by the researcher by providing a list containing several questions to the respondents. The selected respondents were visitors of Mount Salak Endah tourism object that also visited Puncak (Peak) tourism object in Bogor regency.

(2) Documentation; Documentation method was used to collect secondary data through existing documents as supporting data in this research.

The population in this research was tourists visiting Mount Salak Endah Tourism Object. The basis for determining the sample was Purposive sampling by selecting the sample purposively, the number of respondents taken was based on research methods. Determination of the number of samples in this research used Isaac Michael Method (Arikunto, 2013) with the following equation:

Where:

$$
\mathrm{n}=\frac{\left(\mathrm{Z}_{\propto / 2}\right)^{2}}{\mathrm{e}^{2}}
$$

$\mathrm{n}=$ Number of Samples

$\mathrm{Z}=$ Confidence/significance level

$\alpha=1-$ significance, and

$e=$ Error rate

From the calculation using the above equation, it was obtained the number of samples of 96 people by the researcher rounded to 100 . There were 100 respondents interviewed consisting of tourists in Mount Salak Endah tourism object. 100 respondents were taken as samples because the number of tourist population was unknown. Data were collected by questionnaires prepared for each respondent (Hutasorit and Sari, 2014).

This research estimated the demand function of Mount Salak Endah Tourism Object using Travel Cost Method (TCM). The difference was that this research used variables of perceptions about tourism object, amenity and the environment in Mount Salak Endah. This travel cost method examined the costs incurred by individuals to visit recreational areas (Salma and Susilowati, 2014). By determining the pattern of consumer spending, it can be assessed how the value given by consumers to natural resources and the environment. Travel Cost Method was performed by using information about the amount of money spent to reach the recreational area to estimate the value of benefits from efforts to change the environmental quality of the visited recreational area. The form of its function as in the research framework is as follows:

$$
Q_{i j}=f\left(C_{i}, C s_{i}, I_{i}, T_{i}, T s_{i}, P_{i}, P s_{i}, P s w_{i}, P k l_{i}, P k_{i}\right)
$$

Where:

$Q_{i} \quad$ : Number of visits by individual $i$ to Mount Salak Endah

$\mathrm{C}_{i} \quad$ : Travel costs incurred by individual $i$ to visit the location of Mount Salak Endah

CSi : Travel costs incurred by individual $i$ to visit other similar tourism object

li : Income of individual i.

$\mathrm{Ti}$ : Length of journey or distance traveled by individual i to visit Mount Salak Endah

TSi : Length of journey or distance traveled by individual $i$ to visit other similar tourism object 
Pi : Perception on Admission Ticket Price of Mount Salak Endah

Psi : Perception of Admission Ticket Price of Other Similar Tourism Object

Pswi : Perception of individual i on Mount Salak Endah tourism object.

Pkli : Perception of individual i on the environmental condition of Mount Salak Endah tourism object

Pkui: Perception of individual i on the culinary of Mount Salak Endah tourism object

In statistical criteria, 3 tests were applied in this analysis. These three tests are partial significance test ( $t$-test), coefficient of determination (pseudo $R^{2}$ dan count $R$ ), and simultaneous significance test (LR stat).

\section{RESULT AND DISCUSSION}

\section{Classical Assumption Test}

The results of normality test indicate normally distributed residual value, because the significance value is greater than the error rate of $0.05 \%$. The one-sample Kolmogorov-Smirmov test indicates that the Kolmogorov-Smirmov value is 0.593 and the error probability value is $87.3 \%$ greater than 0.05 . Thus, $\mathrm{HO}$ is accepted because the residuals are normally distributed.

The multicolinearity test indicates a linear correlation between some or all of the explanatory variables of the regression model (Gujarati and Porter, 2009). The following table indicates that there is no multicolinearity, because VIF value does not exceed 10 and Tolerance value is less than 0.10 .

Table 2. Multicolinearity Test

\begin{tabular}{lcc}
\hline Independent Variable & Tolerance & VIF \\
\hline Travel costs to Mount Salak Endah & 0.693 & 1.444 \\
Travel Costs to Peak (Puncak) & 0.779 & 1.283 \\
Individual Income & 0.787 & 1.271 \\
Length of Journey to Mount Salak Endah & 0.584 & 1.711 \\
Length of Journey to Peak (Puncak) & 0.635 & 1.575 \\
Perception of Admission Price of Mount Salak Endah & 0.878 & 1.139 \\
Perception of Adminission Price of Peak (Puncak) & 0.881 & 1.134 \\
Perseption of Tourism Facilities & 0.858 & 1.166 \\
Perseption of Environmental Condition & 0.872 & 1.146 \\
Perception of Culinary & 0.890 & 1.123 \\
\hline
\end{tabular}

The heteroscedasticity test aims to test whether there is a variance inequality of residuals in the regression model. Heteroscedasticity test in the research was performed by using Glejser test by regressing the absolute residual to the existing independent variables.

Table 2. Glejser Test

\begin{tabular}{lrr}
\hline Independent Variables & \multicolumn{1}{c}{$\beta$} & t-statistic \\
\hline Travel Cost to Mount Salak Endah (Ci) & 0.076 & 0.241 \\
Travel Cost to Peak (Csi) & -0.246 & -1.108 \\
Individual Income (li) & 0.164 & 0.376 \\
Length of Journey To Mount Salak Endah (Ti) & -0.058 & -0.778 \\
Length of Journey to Peak (Tsi) & 0.106 & 1.431 \\
Perception of Admission Ticket Price of Mount Salak Endah (Phi) & -0.043 & -0.518 \\
Perception of Admission Ticket Price of Peak (Phsi) & -0.067 & -0.803 \\
Perception of Tourism Facilities (Psri) & -0.037 & -0.475 \\
Perception of Environmental Condition (Pli) & 0.019 & 0.195 \\
Perception of Culinary (Pkui) & 0.132 & 1.522 \\
\hline
\end{tabular}


Based on the results of classical assumption test, the classical assumption for ordinary least squre (OLS) method can be met, so that the analysis result can be used to analyze the demand of tourists to visit Mount Salak Endah tourism object, where the independent variables are travel cost to Mount Salak Endah, the travel cost to other similar tourism object (Peak), Individual income, length of journey to Mount Salak Endah tourism object, length of journey to other similar tourism object (Puncak), perceptions of admission ticket price of Mount Salak Endah, perception of admission ticket price of other similar tourism object (Peak), perception of tourism facilities, perception of environmental condition and perception of culinary.

\section{Hypothesis Testing and Discussion}

In the hypothesis testing, it is presented several tests in accordance with multiple linear regression model, namely coefficient of determination $\left(R^{2}\right)$ test, simultaneous test ( $F$ test) and partial test (t test). Based on the tests, it can be obtained the goodness of fit and variables affecting the dependent variable.

The coefficient of determination value $\left(\operatorname{Adj} R^{2}\right.$ ) shows the value of 0.331 . It means that variability of dependent variable can be explained by variability of independent variable by $33.1 \%$. While the remaining of $66.9 \%$ are explained by other independent variables that are not included in the regression model.

$F$ value is 4.255 with a significance level of 0.05 . Seeing from the significant $F$ value, it is obtained that the value of F table with DF1 $=10$ and DF2 = 97-10-1=86 is 1.94 . Thus, it is obtained $\mathrm{F}$ count (4.255) > F table (1.94). This means that all independent variables simultanously have a significant effect on the number of visits to Mount Salak Endah tourism object. Meanwhile, the partial test (t-test) indicates that the independent variables partially have a significant effect on the number of visits to Mount Salak Endah tourism object.

Table 3. Result of Regression Analysis of Demand to Mount Salak Endah Tourism Object

\begin{tabular}{|c|c|c|c|}
\hline \multirow[t]{2}{*}{ Independent Variables } & \multicolumn{3}{|c|}{$\begin{array}{l}\text { Dependent Variables: Number of Visits } \\
\text { (Qi) }\end{array}$} \\
\hline & $\mathrm{B}$ & t-statistic & P-Value \\
\hline Constant & -3.740 & -0.651 & 0.517 \\
\hline Travel Cost to Mount Salak Endah (Ci) & 0.148 & 0.241 & 0.810 \\
\hline Travel Cost to Peak (Csi) & 0.336 & 0.779 & 0.438 \\
\hline Individual Income (li) & 0.476 & 0.562 & 0.576 \\
\hline Length of Journey to Mount Salak Endah (Ti) & -0.754 & -5.204 & $0.000 * * *$ \\
\hline Length of Journey to Peak (Tsi) & 0.501 & 3.487 & $0.001 * * *$ \\
\hline $\begin{array}{l}\text { Perception of Admission Ticket Price of Mount salak } \\
\text { Endah (Phi) }\end{array}$ & -0.179 & -1.114 & 0.268 \\
\hline Perception of Admission Ticket Price of Peak (Phsi) & -0.310 & -1.900 & $0.061^{*}$ \\
\hline Perception of Tourism Facilities (Psri) & 0.314 & 2.061 & $0.042 * *$ \\
\hline Perception of Environmental Condition (Pli) & 0.163 & 0.859 & 0.393 \\
\hline Perception of Culinary (Pkui) & 0.304 & 1.807 & $0.074 *$ \\
\hline F-statistic & 4.255 & \multicolumn{2}{|c|}{$* * *$ Significant $1 \%$} \\
\hline Prob (F-statistic) & 0.000 & \multicolumn{2}{|c|}{ ** Significant 5\% } \\
\hline$R^{2}$ & 0.331 & \multicolumn{2}{|c|}{ * Significant 10\% } \\
\hline
\end{tabular}

Based on the data obtained, it is performed a regression to generate the demand curve of tourist visit to be examined. The model used is the number of tourist visits affected by travel cost travel to Mount Salak Endah, travel cost to other similar tourism object (Peak), individual income, length of journey to Mount Salak Endah tourism object, length of journey to other similar tourism object (Peak), perception of tourism facilities in Mount Salak Endah, perception of admission ticket price of Mount Salak Endah tourism object, perception of admission ticket price of other similar tourism object (Peak), perception of environmental condition and perception of culinary. 
Based on the results of statistical analysis of ten independent variables, there are five independent variables in this research that have significant effect on the number of tourist visits to Mount Salak Endah tourism object, namely 1) length of journey to Mount Salak Endah tourism object (Ti); 2) length of journey to other similar tourism object (Peak) (Tsi), 3) perception of admission ticket price of other similar tourism object (Peak) (TSi); 4) Perception of tourism facilities (Psri); and 5) perception of culinary (Pkui).

The constant value of -3.740 can be interpreted that if all the independent variables, namely travel cost to Mount Salak Endah tourism object $(\mathrm{Ci})$, travel cost to other similar tourism object (Peak) (Csi), individual income (li), Length of journey to Mount Salak Endah tourism object (Ti), length of journey to other similar tourism object (Peak) (Tsi), perception of admission ticket price of Mount Salak Endah (Phi), perception of admission ticket price to other similar tourism object (Peak) (TSi), perception of tourism facilities (Psri), perception of environmental conditions (Pli) and perception of culinary (Pkui), are considered equal to zero or constant, then the number of visits is -3.740 times in one year.

The length of journey to Mount Salak Endah with coefficient value of -0.754 means that if the length of journey to Mount Salak Endah tourism object increases by 1 hour, then the number of visits to Mount Salak Endah decreases by 0.754 or if the length of journey to the tourism object increases by 1.33 hours, then the number of visits to Mount Salak Endah decreases by 1 time of visit. The coefficient of length of journey to Mount Salak Endah tourism object can be interpreted that the further distance of the tourists from Mount Salak Endah, the less likely to visit or revisit to Mount Salak Endah. The description of the respondents indicates that most of the tourists visiting Mount Salak Endah come from Bogor and regions adjacent to Bogor Regency, such as Jakarta, Bekasi and Tangerang, there was only 1 respondent from Bandung. The effect of these variables shows that consumers who can reach Mount Salak Endah tourism object are relatively limited. The length of journey is affected by distance, facilities and infrastructure during travel. In addition, travel condition from Bekasi, Jakarta, Tangerang and Depok to Mount Salak Endah is traffic congestion. Thus, it affects the length of journey.

The result of this research is in accordance with the results of previous research conducted by Wijayanti and Hastuti (2008) stating that the length of journey has a negative and significant effect that can reduce the number of visits to the tourism object. Length of journey to other similar tourism object (Peak) with coefficient value of 0.501 means that if length of journey to other similar tourism object (Peak) increases by 1 hour, then the tourist visit to Mount Salak Endah increases by 0.501 or if the length of journey to other similar tourism object (Peak) increases by 1.99 hours, then the number of visits to Mount Salak Endah tourism object will increase by 1 time visit with the assumption that the travel cost to Mount Salak Endah tourism object (Ci), travel cost to other similar tourism object (Peak) (Csi), individual income (li), length of journey to Mount Salak Endah tourism object (Ti), length of journey to other similar tourism object (Peak) (Tsi), perception of admission ticket price of Mount Salak Endah (Phi), perception of admission ticket price of other similar tourism object (Peak) (TSi), perception of tourism facilities (Psri), perception of environmental condition (Pli) and perception of culinary (Pkui) are constant, then the number of demands to Mount Salak Endah tourism object will increase. Seeing from the length of journey, the positive coefficient value indicates that the Peak (Puncak) tourism area and Mount Salak Endah tourism object are mutually substituted. The journey condition from the area of origin to Peak tourism area is further and the traffic jam is worse compared to the travel condition to Mount Salak Endah tourism object. This indicates that Mount Salak Endah tourism object has potential as an alternative Peak (Puncak) tourism area.

The result of this research is in accordance with previous research conducted by Wijayanti and Hastuti (2008) and Anggraeni (2013) stating that the length of journey to other similar tourism object as an alternative has a positive and significant effect on the number of visits to tourism objects examined.

Perception of admission ticket price of other similar tourism object (Peak) with the regression coefficient value of -0.310 points means that if the admission ticket price of other similar tourism object (Peak) increases by 1 point, then the number of visits will decrease by 0.310 or 1 time of visit 
with the assumption that travel cost to Mount Salak Endah tourism object (Ci), length of journey to other similar tourism object (Peak) (Csi), individual income (li), length of journey to Mount Salak Endah tourism object (Ti), length of journey to other similar tourism object (Peak) (Tsi), perception of admission ticket price of Mount Salak Endah (Phi), perception of admission ticket price to other similar tourism object (Peak) (TSi), perception of tourism facilities (Psri), perception of environmental condition (Pli) and perception of culinary (Pkui) are constant, then the number of visits to Mount Salak Endah tourism object will increase. This means that if the perception of admission ticket price to Peak tourism object is considered good, then the tendency of tourists to visit Mount Salak Endah will decrease or in other words, if tourists perceive that the admission ticket price to Peak tourism area is more expensive, then the tourists will tend to visit Mount Salak Endah tourism object. The result of this research is in accordance with previous research conducted by Isnan (2016) concluding that the admission ticket price of other similar tourism object has an effect on the level of tourist visits. Thus, when the admission ticket price of other similar tourism object rises, then it will encourage the level of tourist visits to the Bantimurung Bulusaraung National Park. This occurs because the demand refers to a certain relationship between the quantity of goods to be purchased and the price. Where based on the demand approach, there is a relationship between demand and other variables.

The perception of tourism facilities of Mount Salak Endah tourism object with a coefficient of 0.314 points means that if the perception of tourism facilities increases by 1 point, then the number of visits will tend to increase by 0.068 or 1 time visit with the assumption that the travel cost to Mount Salak Endah tourism object (Ci), length of journey to other similar tourism object (Peak) (Csi), individual income (li), length of journey to Mount Salak Endah tourism object (Ti), length of journey to other similar tourism object (Peak) (Tsi), perception of admission ticket price of Mount Salak Endah (Phi), perception of admission ticket price of other similar tourism object (Peak) (TSi), perception of tourism facilities (Psri), perception of environmental condition (Pli) and perception of culinary (Pkui) are constant, then the number of visits to Mount Salak Endah tourism object will increase. This means that if the perception of tourism facilities of Mount Salak Endah can be increased, then it will increase the tendency to visit Mount Salak Endah tourism object.

Perception of culinary with coefficient of 0.304 points means that if the perception of culinary increases by 1 point, then the number of visits to Mount Salak Endah tourism object will increase by 0.304 or 1 time visit with the assumption that the travel cost to Mount Salak Endah tourism object (Ci), travel cost to other similar tourism object (Peak) (Csi), individual income (li), length of journey to Mount Salak Endah tourism object (Ti), length of journey to other similar tourism object (Peak) (Tsi), perception of admission ticket price of Mount Salak Endah (Phi), perception of admission ticket price to other similar tourism object (Peak) (TSi), perception of tourism facilities (Psri), perception of environmental condition (Pli) and perception of culinary (Pkui) are constant, then the number of tourist visits to Mount Salak Endah tourism object will increase. This means that if the perception of culinary in Mount Salak Endah tourism object can be increased, then it will increase the tendency to visit Mount Salak Endah tourism object. Culinary in Mount Salak Endah area is typical with Sundanese cuisine. In addition, the price is relatively cheap and the tourists tend to eat more in this area due to cold temperature.

Similarly, the result of research conducted by Besra (2012) also mentions that culinary tour of Padang City has a very good potential. The foreign tourists remember Indonesia with its typical food of Rendang. Rendang is one culinary in Padang City.

\section{CONCLUSION}

Based on the formulation of problems and research results above, it is obtained conclusions to answer the research question as follows: from ten independent variables analysed, there are five significant independent variables, namely (1) length of journey to Mount Salak Endah tourism object; (2) length of journey to other similar tourism object (Peak), (3) perception of admission ticket price of other similar tourist object (Peak); (4) perception of tourism facilities; and (5) perception of culinary. 
While the other five independent variables have no effect on the number of demand (visits) to Mount Salak Endah tourism object.

Based on the analysis of demand to Mount Salak Endah, it indicates that the demand to visit Mount Salak Endah tourism object is obtained as follows: the length of journey has a negative effect, the length of journey to other similar tourism object (Peak) has a positive effect, perception of admission ticket price of similar tourism object (Peak) has negative effect, perception of facilities in Mount Salak Endah has positive effect; and perception of culinary in Mount Salak Endah tourism object has an effect on the number of visits to Mount Salak Endah tourism object.

Based on the above conclusions, the suggestions of this research are: 1) The strong effect of the length of journey on the number of visits to Mount Salak Endah tourism object implies that the policy to encourage tourism to the area of Mount Salak Endah by improving the transportation infrastructure towards Mount Salak Endah tourism object, improving and adding traffic signs and road markings along the road to Mount Salak Endah tourism object in order to reduce congestion so as to reduce the time or length of journey; 2 ) The effect of perception of facilities in Mount Salak Endah tourism object implies that the region must improve the road to the tourism object, parking lot, restrooms and worship place; 3) The effect of perception of culinary in Mount Salak Endah tourism object implies that the area must provide unique and traditional foods and beverage to the existing ones.

\section{REFERENCES}

Agustine, R., Alikodra, H.S., and Iskandar, E. (2016) Analysis of supply and demand for ecotourism of proboscis monkeys in Gelam Tapin Swamp Forest, South Kalimantan. Media Konservasi, 21(2), 143-151.

Arikunto, S. (2013). Research procedure: A practice approach. Jakarta: Rineka Cipta.

Besra. (2012). Potential culinary tourism in supporting Padang City tourism. Journal of Accounting and Business Research, 12(1).

Gujarati, D.N. and Porter, D.C. (2009). Basic econometric (fifth edition). New York: McGraw-Hill.

Hermawan, H. (2016). Impact of Nglanggeran Tourism Village development on the economy of local communities. Journal of Tourism, 3(2), 105-117.

Hutasorit, A.B.R. and Sari, R.L. (2014). Analysis of demand for foreign tourists traveling in Tuktuk Siadong, Samosir Regency. Journal of Economics and Finance, 2(10), 587-600.

Isnan, W. (2016). Optimal price of Bantimurung Nature Tourism entrance ticket, South Sulawesi. Journal of Forestry Social and Economic Research, 13(3), 155-163.

Salma, I.A. and Susilowati, I. (2014). Demand analysis of Curug Sewu Natural Tourism, Kendal Regency with travel cost approach. Development Dynamics, 1(2), 153-165.

Satria, D. (2009). Strategy for the development of ecotourism based on local economy in the framework of poverty alleviation programs in the District of Malang. Jurnal of Indoneian Applied Economics, 3(1), 37-47.

Wijayanti and Hastuti. (2008.). Economic analysis and tourism management strategies: Case study of Mount Salak Endah tourism area Bogor Regency. Journal of Agricultural Sciences, 13(3). 